\title{
Correction to: Experimental Investigations of the Fe-Mn-Ti System in the Concentration Range of up to 30 at.\% Ti
}

\author{
Alexander Walnsch $^{1} \cdot$ Mario J. Kriegel ${ }^{1} \cdot$ Olga Fabrichnaya $^{1} \cdot$ Andreas Leineweber $^{1}$
}

Published online: 20 May 2020

(C) ASM International 2020

\section{Correction to:}

J. Phase Equilib. Diffus. https://doi.org/10.1007/s11669-020-00804-6

Publisher's Note Springer Nature remains neutral with regard to jurisdictional claims in published maps and institutional affiliations.

In the original article, the corresponding author was incorrectly assigned. The corresponding author should be Mario J. Kriegel.

The original article can be found online at https:// doi.org/10.1007/s11669-020-00804-6.

\footnotetext{
Mario J. Kriegel

mario.kriegel@iww.tu-freiberg.de

1 Institute of Materials Science, TU Bergakademie Freiberg,

Gustav-Zeuner Str. 5, 09599 Freiberg, Germany
} 